\title{
Incidence and Impact of Verticillium dahliae in Soil Associated with Certified Potato Seed Lots
}

\author{
Jeremiah K. S. Dung, Philip B. Hamm, Jordan E. Eggers, and Dennis A. Johnson
}

First and fourth authors: Department of Plant Pathology, Washington State University, Pullman; and second and third authors: Department of Botany \& Plant Pathology, Hermiston Agricultural Research and Extension Center, Oregon State University, Hermiston. Accepted for publication 30 August 2012.

\section{ABSTRACT}

Dung, J. K. S., Hamm, P. B., Eggers, J. E., and Johnson, D. A. 2013. Incidence and impact of Verticillium dahliae in soil associated with certified potato seed lots. Phytopathology 103:55-63.

Verticillium dahliae causes Verticillium wilt of potato and can be found in soil associated with potato seed tubers. The purpose of this research was to quantify $V$. dahliae in soil associated with certified seed tubers and determine if this potential inoculum source is related to disease development in the field. Approximately $68 \%$ of seed lots assayed contained $V$. dahliae-infested soil on seed tuber surfaces (seed tuber soil). Over $82 \%$ of seed lots contained $V$. dahliae in loose seed lot soil obtained from bags and trucks used to transport seed tubers. Most samples contained $\leq 50 \mathrm{CFU} / \mathrm{g}$ but some contained $>500 \mathrm{CFU} / \mathrm{g}$. Most isolates $(93 \%)$ were vegetative compatibility group $4 \mathrm{~A}$. Populations of $V$. dahliae in stem sap increased with increasing inoculum densities in field soils only when $V$. dahliae concentrations in seed tuber soil were low. High concentrations of $V$. dahliae in seed tuber soil resulted in greater stem sap colonization when $V$. dahliae inoculum densities in field soil were low $(P<0.01)$ and resulted in greater pathogen inoculum densities in postharvest field soils $(P=0.04)$. Seed tubers contaminated with $V$. dahliae-infested soils may introduce the pathogen into fields not previously cropped to potato or recontaminate those which have received preplant management practices. Long-term management of $V$. dahliae requires reducing propagules in soil associated with seed lots.
Verticillium dahliae is a soilborne plant pathogen with a wide host range and worldwide distribution. The fungus causes Verticillium wilt of potato resulting in wilting, chlorosis, necrosis, vascular discoloration, premature senescence, and yield reduction $(27,44)$. In North America, vegetative compatibility group (VCG) $4 \mathrm{~A}$ has been found to be the predominant VCG associated with potatoes and is more aggressive than either VCG4B or VCG2 $(25,37,48,49)$. Outside of North America, VCG4B and VCG2 are primarily associated with potato $(2,3,15,28,52)$. Primary inoculum of $V$. dahliae, which is composed of melanized microsclerotia, remains dormant in soil until germination is stimulated by plant root exudates (34). The fungus invades roots, colonizes the vascular system of susceptible hosts, and produces microsclerotia in colonized tissue during host senescence. The disease cycle is completed when infested host debris is returned to the soil and breaks down, which releases microsclerotia into the soil. Soilborne inoculum densities can increase annually if proper management practices are not observed (7,50). Management of Verticillium wilt of potato often begins by reducing primary inoculum to below threshold levels through preplant soil fumigation. The use of resistant cultivars reduces vascular colonization, early vine senescence, and the formation of microsclerotia in stems which serve as primary inoculum (9). Both soil fumigation and the use of resistant cultivars reduce microsclerotia accumulation in the soil. Crop rotation is of only limited benefit due to the wide host range of $V$. dahliae (45), its ability to colonize and persist on the roots of monocots and other nonhost crops (32), and its long persistence in soil $(18,33)$.

The production of certified potato seed tubers in North America is limited to certain seed tuber-producing states and provinces in

Corresponding author: J. K. S. Dung;

E-mail address: jeremiah.dung@oregonstate.edu

http://dx.doi.org/10.1094/PHYTO-04-12-0073-R

(C) 2013 The American Phytopathological Society the United States and Canada. All certified planting stock begins with disease-free plantlets, microtubers, or minitubers which are produced in vitro or under controlled greenhouse conditions (53). The tubers are then planted in the field to expand each certified lot. Thus, the potential exists for tuber-borne diseases to accumulate after each field generation. Seed tubers are shipped to commercial production areas throughout North America which can lead to the long-distance transport of pathogens in or on planting materials.

Verticillium spp. have been found in the vascular system of infected tubers used for seed $(14,37,51)$. The majority of isolates obtained from potato seed tubers in North America have been found to belong to VCG4A and VCG4B (37). However, Verticillium-infected seed tubers are less important than soilborne inoculum to the development of disease symptoms, reductions in yield, infection of progeny tubers, and the production of inoculum in host debris during the current season $(11,12,22,42)$. Nevertheless, greenhouse studies demonstrated that isolates obtained from seed tubers can cause Verticillium wilt of potato when isolated into pure culture and introduced into soil. Therefore, infected seed tubers may contribute to the movement and establishment of $V$. dahliae into potato production areas (12).

Soils infested with $V$. dahliae that are associated with seed tubers may provide additional sources of inoculum in commercial potato fields. This may be particularly significant after the expensive practice of soil fumigation. Other soilborne pathogens such as Fusarium solani f. sp. pisi, the sugar beet cyst nematode (Heterodera schachtii), and Beet necrotic yellow vein virus, which is vectored by Polymyxa betae, can be moved in soil associated with pea seed and harvested sugar beets $(5,20,21)$. In potato, $V$. dahliae inoculum may potentially be found in infested soil directly adhered to the surface of seed tubers ("seed tuber soil") or in loose soil associated with the transport, handling, and planting of seed lots ("loose seed lot soil") $(1,43)$. Infested seed tuber soil may be an important source of $V$. dahliae inoculum in commercial fields and, since seed tubers are not washed prior to 
planting, can introduce the pathogen into planting furrows and possibly cause Verticillium wilt in the current or future cropping seasons. Loose seed lot soil, if infested and left near a field after planting, represents a potential problem for growers in terms of waste management and disposal since infested loose seed lot soil may blow or wash inoculum into fields or irrigation water during rain or wind events. The impact of introducing infested soil into commercial production fields is of particular concern since the disease threshold for Verticillium wilt of potato can be less than $10 \mathrm{CFU} / \mathrm{g}$ of field soil (40).

Up to $41 \%$ of seed lots were shown to contain $V$. dahliaeinfested soil and populations in a single seed lot were estimated to be as high as $10^{6} \mathrm{CFU} / \mathrm{g}$ of soil and plant debris $(14,43)$. Increased incidence of wilt and reduced yields were previously associated with Verticillium-infested soil associated with seed tubers $(41,43)$. However, the effects of infested seed tuber soil on in planta colonization of potato by $V$. dahliae and subsequent populations of the pathogen in postharvest field soils are not known. The objectives of this research were to (i) quantify $V$. dahliae in seed tuber soil and loose seed lot soil from certified potato seed lots; (ii) identify the VCGs of $V$. dahliae isolates collected from this soil; and (iii) test the hypothesis that increased concentrations of $V$. dahliae inoculum in seed tuber soil are related to increased populations of $V$. dahliae in plants and field soils and decreased potato yields.

\section{MATERIALS AND METHODS}

Verticillium assays. Soil adhering to the surface of potato seed tubers (seed tuber soil) and loose soil from bags and trucks associated with seed lot handling (loose seed lot soil) were assayed for $V$. dahliae infestation on semiselective medium. A total of 55, 64, and 108 certified seed lots intended for commercial production fields in the Columbia Basin of Washington and Oregon were obtained in 2009, 2010, and 2011, respectively. Of those, 39, 59, and 41 lots were sampled for seed tuber soil in 2009, 2010, and 2011, respectively, because seed tubers in some lots were free of soil. Seed tuber soil was obtained by scraping the surface from a sample of up to 35 seed tubers from each lot. An average of 31 seed tubers were sampled per lot because some seed lot samples that were received contained less than 35 seed tubers. The soil was then bulked by lot, passed through a number 4 sieve (4.75 mm wire mesh), and a 70- to $100-\mathrm{mg}$ subsample was dry-plated onto NP-10 medium (4). Between 0.5 and $1.5 \mathrm{~kg}$ of loose seed lot soil was collected from a potato transport truck bed or conveyer belt. This range depended on how much soil was available, as some lots had more loose soil than others. Samples of loose seed lot soil were bulked by lot, sieved, and a 70- to $100-\mathrm{mg}$ subsample of soil was dry-plated in a similar manner. Plates were incubated at room temperature for 2 weeks and visually inspected for $V$. dahliae colonies using a dissecting microscope. The black dot pathogen, Colletotrichum coccodes, was also quantified since it was frequently observed from samples plated on NP-10 medium. The number of CFUs per gram of seed tuber soil and loose seed lot soil was calculated based on the amount of soil plated and the number of colonies observed.

VCG assays. Pure cultures of $V$. dahliae isolates were obtained from the above samples for VCG analysis (24). VCGs of isolates were determined by pairing nitrate-nonutilizing (nit) mutants with standardized tester strains obtained from R. Rowe (The Ohio State University, Wooster). The tester strains used for each VCG were as follows: V-44 (VCG 1), T9 (VCG 1A), PH (VCG 2A), 115 (VCG 2B), 70-21 (VCG 3), BB (VCG 4A), S39 (VCG 4B), and MT (VCG 6). Chlorate-resistant nit mutants of $V$. dahliae were obtained by culturing wild-type isolates on $1.5 \%$ water agar amended with dextrose $(2 \mathrm{~g} /$ liter $)$ and potassium chlorate ( $50 \mathrm{~g} /$ liter) for 2 to 4 weeks at room temperature $\left(22\right.$ to $\left.23^{\circ} \mathrm{C}\right)$. Subcultures of nit mutants were obtained from thin, hyaline, fast- growing sectors lacking aerial hyphae and microsclerotia. Each nit mutant was paired with known Nit1 and NitM VCG testers on minimal media (24) at least twice. Plates were incubated in the dark at room temperature for 10 to 21 days. Plates were visually checked for complementation reactions and rated as no complementation (no reaction), weak complementation (growth of aerial hyphae but no microsclerotia formation), moderate complementation (growth of aerial hyphae and sparse microsclerotia formation), or strong complementation (full wild-type growth with growth of aerial hyphae and microsclerotia formation). All reactions were recorded but only tests resulting in strong complementation were considered a positive result.

Field experiments. Twelve certified seed lots, six each of cultivars Russet Norkotah and Russet Burbank, were planted in field trials conducted in 2010 and 2011. All seed lots were used in commercial plantings in the Columbia Basin of Oregon and Washington. The seed lots were obtained from Idaho, Montana, Oregon, and Washington state seed growers in 2010; and from the same four states and Alberta, Canada in 2011. Seed tuber soil was assayed for $V$. dahliae as described above to select seed lots to use for planting. Loose seed lot soil from bags was also quantified and correlations between $V$. dahliae concentrations in seed tuber soil and loose seed lot soil were identified using PROC CORR in SAS. After a 2-week incubation period, colonies of $V$. dahliae were counted and plate count results from four replicate plates determined which seed lots would be used in the experiment. For each trial and cultivar, a total of three seed lots with low concentrations ( 0 to $20 \mathrm{CFU} / \mathrm{g}$ ) of $V$. dahliae in seed tuber soil and three seed lots with high concentrations ( $>20 \mathrm{CFU} / \mathrm{g}$ ) of $V$. dahliae in seed tuber soil were selected to test the hypothesis that high concentrations of $V$. dahliae in seed tuber soil are related to increased populations of the pathogen in plants, higher inoculum densities and field soils, and decreased potato yields.

Field trials were located at the Hermiston Agricultural Research and Extension Center south of Hermiston, Oregon in both years. The fields were cropped to winter wheat during the previous year and fumigated with metam sodium at a rate of approximately 374 liters/hectare the fall prior to planting. The trials were separated by cultivar and treatments were assigned in a randomized complete block design with four replications (blocks) for each cultivar. Individual replications of each seed lot were planted as single row plots approximately $0.85 \mathrm{~m}$ wide by $7 \mathrm{~m}$ long. Five 2.54 by $32 \mathrm{~cm}$ soil cores were collected along the length of each plot prior to planting. The soil cores were combined, processed, and plated onto NP-10 medium to quantify $V$. dahliae inoculum densities in each plot as described above. Seed tubers were hand cut into $\sim 57 \mathrm{~g}$ pieces prior to planting and each treatment replication consisted of 30 seed pieces planted in a single row and spaced 20 to $23 \mathrm{~cm}$ apart. Each block consisted of six treatments, three seed lots with high $V$. dahliae concentrations and three seed lots with low $V$. dahliae concentrations of a single cultivar. An approximately $3 \mathrm{~m}$ break occurred between plots and a single row of purple potatoes was planted on each edge to serve as a buffer. Trials were hand-planted on 10 May 2010 and on 20 May 2011.

Disease severity was assessed at midseason by randomly sampling stems to quantify populations of $V$. dahliae in plant sap using methods adapted from Hoyos et al. (23). Stems were sampled from each plot on 91 and 95 days after planting at mid to late growth stage IV. Five stem sections $(19 \mathrm{~cm}$ in length and sampled equally from above-ground and below-ground sections) were collected, one from each of five plants per replication. Stems were washed with soap and water, surface-disinfested with $0.5 \%$ $\mathrm{NaOCl}$ for $3 \mathrm{~min}$, triple-rinsed with tap water, and then air-dried. Stems were then sprayed with $95 \%$ ethanol, flamed, cut in half longitudinally, and crushed. Approximately $500 \mu \mathrm{l}$ of sap was collected from each stem and kept on ice or at $4^{\circ} \mathrm{C}$ until use. Two hundred microliter aliquots of plant sap from each of five stems were combined and serially diluted into $9 \mathrm{ml}$ of sterile distilled 
water. The sap dilution was further diluted into $10^{-2}$ and $10^{-3}$ dilutions. A 250- $\mu$ l aliquot of each dilution was added to each of four NP-10 plates. Plates were incubated for 2 weeks at room temperature and evaluated for $V$. dahliae microsclerotia. The $10^{-3}$ dilution, which had a moderate number of $V$. dahliae colonies, was used to calculate $\mathrm{CFU} / \mathrm{ml}$ of plant sap. Vine decline ratings $(0=$ alive and vigorous, $10=$ dead) were recorded in 2011 at 101, 110, 117, and 124 days after planting and converted to area under disease progress curves (AUDPC) using the following formula: $\sum_{i}^{n-1}\left[\left(Y_{i}+\right.\right.$ $\left.\left.Y_{i+1}\right) / 2\right]\left(t_{i+1}-t_{i}\right)$, where $Y_{i}=$ cumulative vine decline rating at the $i$ th observation, $t_{i}=$ time (days postinoculation) at the $i$ th observation, and $n=$ number of observations.

Yield and grade of the different size classes (under $113 \mathrm{~g}, 113$ to $226 \mathrm{~g}, 227$ to $340 \mathrm{~g}$, over $340 \mathrm{~g}$, and culled tubers) were determined after harvesting all potatoes from each plot 149 days after planting in 2010 and 129 days after planting in 2011. Tubers in the 113 to $226 \mathrm{~g}$ ( 4 to $8 \mathrm{oz}$ ) and 227 to $340 \mathrm{~g}$ ( 8 to $12 \mathrm{oz}$ ) size classes were considered marketable. Smaller tubers, larger tubers, and tubers classified as culls were considered nonmarketable. Twenty-five tubers were randomly selected from each treatment replicate from the two marketable size classes. Soil scraped from the surface of harvested progeny tubers (progeny tuber soil) was evaluated for $V$. dahliae as described above. Field soil was assayed following harvest to quantify $V$. dahliae levels in field plots, also as described above.

Statistical analysis. Data for counts of $V$. dahliae CFUs in stem sap, progeny tuber soil, and postharvest field plot soil in response to low and high $V$. dahliae concentrations in seed tuber soil were analyzed using Poisson regression (30) and the GENMOD procedure in SAS 9.2 (SAS Institute, Cary, NC). Data for AUDPC and yield in response to low and high concentrations of the pathogen in seed tuber soil were analyzed by one-way analysis of variance (ANOVA) using PROC MIXED in SAS. Separations of treatment means were performed using Fisher's protected least significant difference test when the $F$ test for the model was significant $(P<0.05)(16)$. Simple and multiple linear regression analyses were performed using PROC REG to identify relationships between quantitative independent variables (preplant concentrations of $V$. dahliae in seed tuber soil and field plot soil) and dependent variables (populations of $V$. dahliae in stem sap, inoculum densities in progeny tuber soil and postharvest field plot soil, and total yield). Data for CFUs in stem sap, progeny tuber soil, and postharvest field plot soil were log-transformed to satisfy assumptions of normality. Simple and multiple linear regression models for each dependent variable were selected based on $R^{2}, P$ values $(\alpha=0.05)$, and Mallows' $C_{\mathrm{p}}(31)$. Analysis of covariance (ANCOVA) was performed in SAS (PROC MIXED) to test for interactions between low and high concentrations of $V$. dahliae in preplant seed tuber soil, the categorical independent variable, and dependent variables using preplant concentrations of $V$. dahliae in field plot soil as the covariate $(29,30)$. Data for CFUs in stem sap, progeny tuber soil, and postharvest field plot soil were logtransformed to satisfy assumptions of normality for ANCOVA.

\section{RESULTS}

Verticillium assays. Levels of $V$. dahliae in soil adhered to the surface of seed tubers (seed tuber soil) varied greatly, ranging from 0 to approximately 2,000 CFU/g of soil (Fig. 1A). Over $23 \%$ of the seed lots assayed contained between 1 and $20 \mathrm{CFU} / \mathrm{g}$ of seed tuber soil between 2009 and 2011. High levels of $V$. dahliae (101 to over $500 \mathrm{CFU} / \mathrm{g}$ ) were found in the seed tuber soil of $19 \%$ of seed lots assayed over all 3 years. Seed tuber soil from six seed lots contained over $500 \mathrm{CFU} / \mathrm{g}$ soil in 2010. Approximately $42 \%$ of seed lots contained $V$. dahliae in loose soil from bags and trucks associated with seed lot handling and transport (loose seed lot soil). Most samples of loose seed lot soil contained less than $20 \mathrm{CFU} / \mathrm{g}$ of soil (Fig. 1B). However, V. dahliae levels ranging from 50 to over $500 \mathrm{CFU} / \mathrm{g}$ were observed in loose seed lot soil samples in at least $15 \%$ of all seed lots tested. Colletotrichum coccodes from seed tuber soil was found in $22 \%$ of seed lots between 2009 and 2011 at levels between 1 and 174 CFU/g of soil (Fig. 2A). Levels of C. coccodes in loose seed lot soil was generally less than $20 \mathrm{CFU} / \mathrm{g}$ of soil, but one seed lot contained $412 \mathrm{CFU} / \mathrm{g}$ of soil (Fig. 2B).

$V$. dahliae was detected in the seed tuber soil of 25 of $39(64 \%)$, 41 of $59(69 \%)$, and 28 of $41(68 \%)$ seed lots assayed in 2009, 2010 , and 2011, respectively, and was observed in loose seed lot soil from 46 of $55(84 \%), 51$ of $64(80 \%)$, and 90 of $108(83 \%)$ of seed lots during the three respective years. $C$. coccodes was recovered from seed tuber soil in 1 of $39(3 \%)$ seed lots in 2009, 6 of $59(10 \%)$ seed lots in 2010, and 24 of $41(59 \%)$ seed lots in 2011. Assays of loose seed lot soil detected $C$. coccodes in 13 of $55(24 \%), 38$ of $64(59 \%)$, and 60 of $108(56 \%)$ seed lots assayed in 2009, 2010, and 2011, respectively.

VCG assays. Vegetative compatibility group analysis indicated that all $V$. dahliae isolates belonged to VCG4. Fourteen of sixteen isolates from seed tuber soil belonged to the VCG4A subgroup and one isolate from seed tuber soil was characterized as VCG4B. A single isolate from seed tuber soil that exhibited strong complementation with VCG4A and VCG4B was classified as VCG4A/B. All 16 isolates obtained from loose seed lot soil were characterized as VCG4A. Some VCG4A isolates exhibited weak complementation with the VCG4B tester strains and vice versa. However, these reactions were insufficient to warrant a VCG4A/B designation.
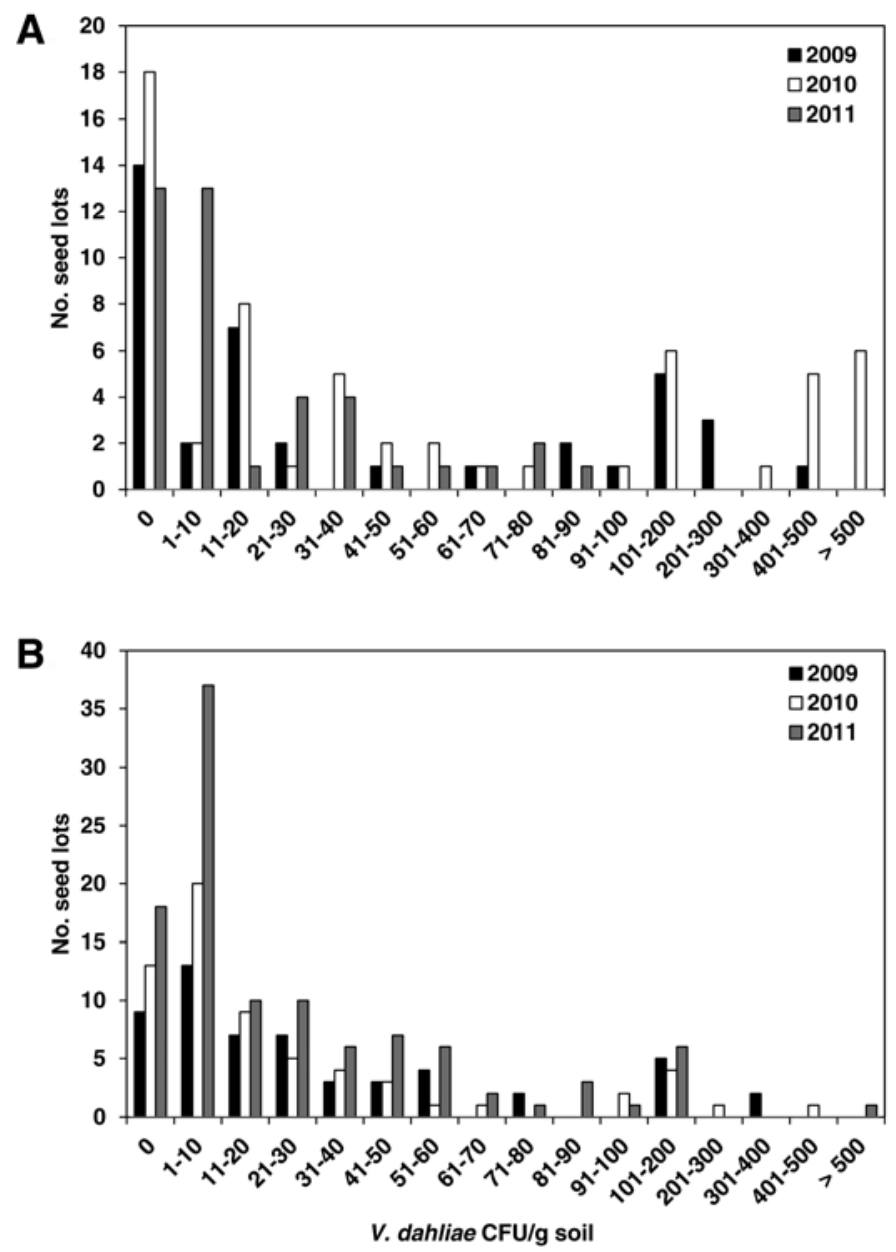

Fig. 1. Colony forming units of Verticillium dahliae in A, seed tuber soil adhering to certified seed tubers and $\mathbf{B}$, loose seed lot soil collected from bags used to transport certified seed lots intended for Columbia Basin production fields. 
Field experiments. Seed lots of Russet Burbank with low levels of $V$. dahliae in seed tuber soil that were selected for use in field experiments contained between 8 and $16 \mathrm{CFU} / \mathrm{g}$ of seed tuber soil and between 14 and $20 \mathrm{CFU} / \mathrm{g}$ of loose seed lot soil in 2010 (Table 1). In 2011, V. dahliae was not detected in seed tuber soil of Russet Burbank seed lots with low levels of the pathogen, but these lots contained between 2 and $4 \mathrm{CFU} / \mathrm{g}$ of loose seed lot soil. Russet Burbank seed lots with high levels of $V$. dahliae contained 26 to $38 \mathrm{CFU} / \mathrm{g}$ of seed tuber soil and $20 \mathrm{CFU} / \mathrm{g}$ of loose seed lot soil in 2010, and contained 34 to $90 \mathrm{CFU} / \mathrm{g}$ of seed tuber soil and 88 to $138 \mathrm{CFU} / \mathrm{g}$ of loose seed lot soil in 2011. Seed lots of Russet Norkotah with low levels of $V$. dahliae contained between 0 and $4 \mathrm{CFU} / \mathrm{g}$ of seed tuber soil and between 0 and $16 \mathrm{CFU} / \mathrm{g}$ of loose seed lot soil in 2010 (Table 1). The pathogen was not detected in seed tuber soil of Russet Norkotah seed lots with low levels of $V$. dahliae in 2011 but was detected in loose seed lot soil at levels between 6 and $10 \mathrm{CFU} / \mathrm{g}$. Russet Norkotah seed lots with high levels of $V$. dahliae contained between 24 and $92 \mathrm{CFU} / \mathrm{g}$ of seed tuber soil and between 20 and $162 \mathrm{CFU} / \mathrm{g}$ of loose seed lot soil in 2010, while seed lots with high levels of $V$. dahliae contained between 28 and $74 \mathrm{CFU} / \mathrm{g}$ of seed tuber soil and between 56 and $630 \mathrm{CFU} / \mathrm{g}$ of loose seed lot soil in 2011.

A significant positive correlation between levels of $V$. dahliae in seed tuber soil and loose seed lot soil was observed for Russet Burbank in $2011(r=0.955, P=0.003, n=6)$ but not in $2010(r=$ $0.841, P=0.159)$ which had a reduced sample size $(n=4)$. A significant positive correlation between levels of $V$. dahliae in
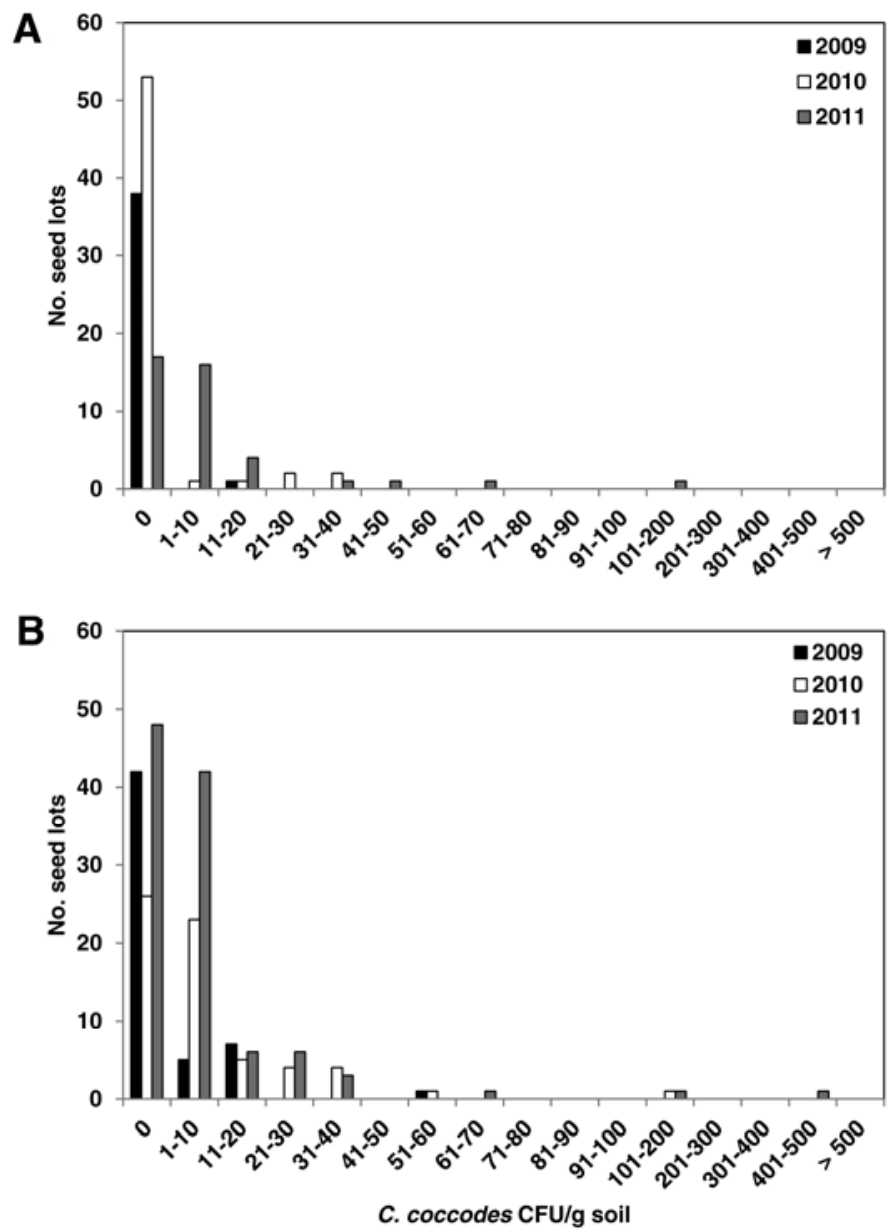

Fig. 2. Colony forming units of Colletotrichum coccodes in $\mathbf{A}$, seed tuber soil adhering to certified seed tubers and $\mathbf{B}$, loose seed lot soil collected from bags used to transport certified seed lots intended for Columbia Basin production fields. seed tuber soil and loose seed lot soil was observed for Russet Norkotah in $2010(r=0.921, P=0.009, n=6)$ and in $2011(r=$ $0.907, P=0.013, n=6)$. When data from both years were combined the correlation was significant for both Russet Burbank ( $r=$ $0.872, P \leq 0.001)$ and Russet Norkotah $(r=0.659, P=0.020)$ (Fig. 3). Preplant levels of $V$. dahliae in field plot soils ranged between 12 and $20 \mathrm{CFU} / \mathrm{g}$ for Russet Burbank plots and 5 and 9 CFU/g for Russet Norkotah plots in 2010 (Table 1). All field plots in 2011 contained between 1 and $5 \mathrm{CFU} / \mathrm{g}$ of soil and $V$. dahliae levels were uniform across all plots for both cultivars in 2011.

$V$. dahliae was present in all stem sap samples from Russet Burbank and 23 out of 24 stem samples from Russet Norkotah in 2010. The pathogen was observed in 23 of 24 and 22 of 24 stem sap samples from Russet Burbank and Russet Norkotah, respectively, in 2011. $V$. dahliae populations in stem sap at midseason were not significantly related to $V$. dahliae concentrations in seed tuber soil in $2010(P>0.05)$. In 2011, results of Poisson regression indicated that increased populations of $V$. dahliae in stem sap at midseason were associated with seed lots containing high concentrations of $V$. dahliae in seed tuber soil for Russet Burbank $(P=0.049)$ but not Russet Norkotah $(P=0.080)$. Multiple linear regression analysis indicated that increased populations of $V$. dahliae in stem sap of Russet Burbank were related to greater inoculum densities of $V$. dahliae in preplant field soil in 2010 $\left(R^{2}=0.686 ; P=0.042\right)$. A nonsignificant trend of increasing $V$. dahliae populations in Russet Burbank stem sap with increasing concentrations of $V$. dahliae in seed tuber soil was observed in $2011\left(R^{2}=0.545 ; P=0.094\right)$. A significant positive relationship
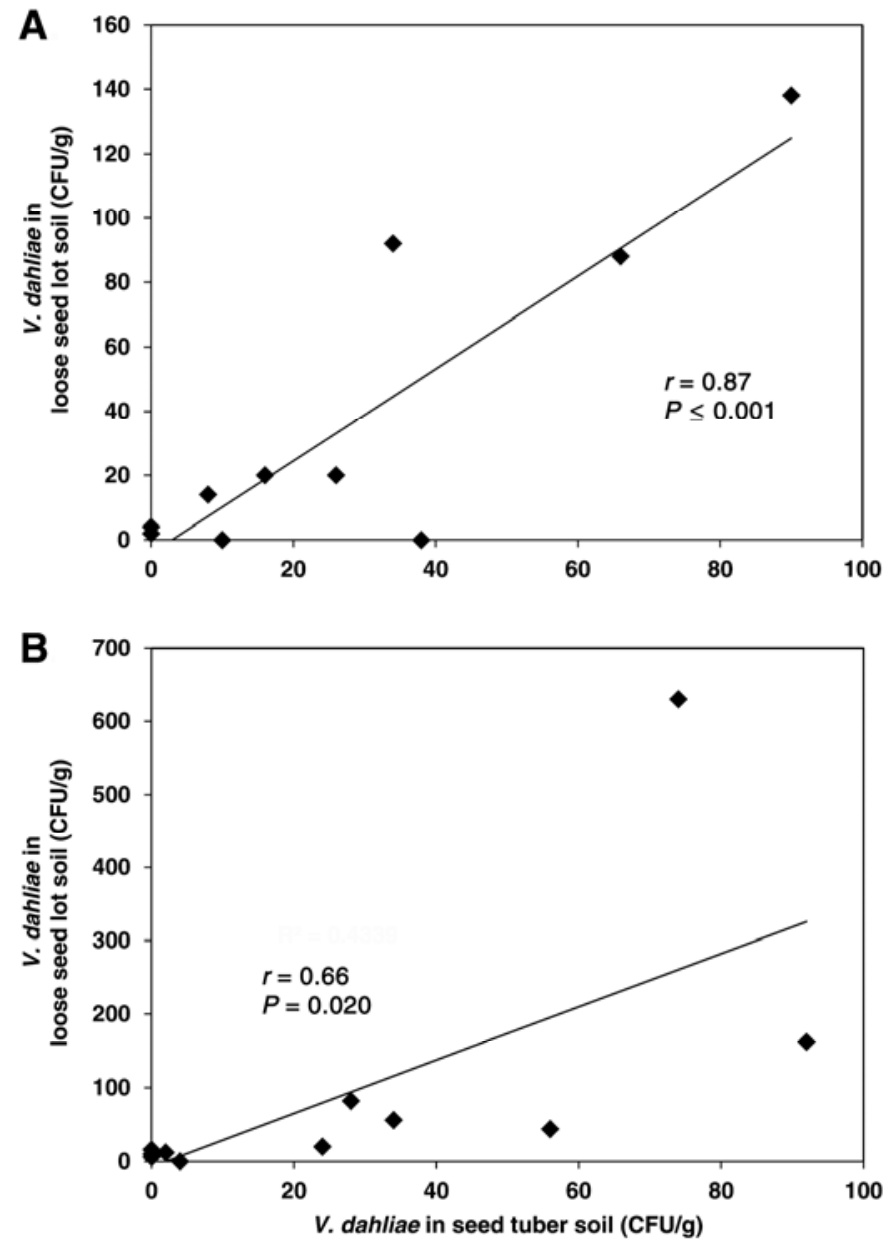

Fig. 3. Correlations between colony forming units of Verticillium dahliae in seed tuber soil adhering to certified seed tubers and loose seed lot soil collected from bags used to transport certified seed lots of A, 'Russet Burbank' and B, 'Russet Norkotah' potato. Data were combined from 2010 and 2011. 
was observed between increased concentrations of $V$. dahliae in field plot soil and increased levels of the pathogen in Russet Norkotah stem sap in $2011\left(R^{2}=0.737 ; P=0.029\right)$ and the combination of preplant levels of $V$. dahliae in both seed tuber soil and field plot soil resulted in an improved model $\left(R^{2}=0.933\right.$; $P=0.018)$. Significant differences in AUDPC were not identified using ANOVA for either Russet Burbank $(P=0.218)$ or Russet Norkotah $(P=0.067)$ in 2011 (Table 1$)$ and regression analysis did not detect significant relationships between AUDPC values and levels of $V$. dahliae in seed tuber soil or preplant field plot soil for Russet Burbank $\left(R^{2}=0.579 ; P=0.079\right)$ or Russet Norkotah $\left(R^{2}=0.492 ; P=0.121\right)$ (data not shown).

The effect of $V$. dahliae in seed tuber soil on yield was not significant for Russet Burbank in $2010(P=0.827)$ or $2011(P=$ $0.069)$ (Table 1). The effect of $V$. dahliae in seed tuber soil on yield of Russet Norkotah was also not significant in 2010 ( $P=$ $0.332)$ or $2011(P=0.140)$ (Table 1). Significant relationships were not observed between yield data and levels of $V$. dahliae in seed tuber soil $(P \geq 0.194)$ or preplant field plot soil $(P \geq 0.086)$ in either year.

Levels of $V$. dahliae in soil scraped from harvested progeny tubers (progeny tuber soil) were not significantly different among low and high levels of the pathogen in seed tuber soil for Russet Burbank in $2010(P=0.239)$ or $2011(P=0.450)$ or for Russet Norkotah in $2010(P=0.074)$ or $2011(P=0.235)$ (Table 1$)$. A significant positive relationship was observed between preplant levels of $V$. dahliae in field plot soils and levels of the pathogen in progeny tuber soil $\left(R^{2}=0.500, P<0.001\right)$ only when data from both cultivars and years were combined (Fig. 4).

Postharvest levels of $V$. dahliae increased in all field plot soils compared to preplant levels and ranged from 16 to $60 \mathrm{CFU} / \mathrm{g}$ of soil in 2010 and 12 to $81 \mathrm{CFU} / \mathrm{g}$ of soil in 2011 (Table 1). Individual field plots exhibited a 1.5- to 6.6-fold increase in
$V$. dahliae propagules in 2010 and a 3.6- to 40.5 -fold increase in 2011 (Fig. 5). Significant differences among postharvest levels of $V$. dahliae in field plot soils were observed for Russet Burbank in 2011 ( $P=0.012)$ but not in $2010(P=0.617)$ or for Russet Norkotah in either year $(P \geq 0.077)$. Significant relationships were not observed between levels of $V$. dahliae in seed tuber soil or preplant field plot soils and postharvest levels of the pathogen in field plot soils for either cultivar in either year $(P \geq 0.118)$.

ANCOVA identified significant differences between the slopes of regression lines of low and high levels of $V$. dahliae in seed tuber soil, the categorical independent variable, and pathogen levels in stem sap, the dependent variable, using levels of $V$. dahliae in field plot soil as the covariate when data from both years were combined. Significant differences in slopes were observed for Russet Burbank $(P=0.005)$, Russet Norkotah $(P=$ $0.005)$, and when data from both cultivars were combined $(P=$ 0.006) (Fig. 6). Increased levels of $V$. dahliae in field plot soils resulted in increased pathogen levels in stem sap in plants grown from seed lots with low levels of $V$. dahliae infestation in seed tuber soil. Increased $V$. dahliae levels in stem sap were observed in plants grown from seed lots with high levels of the pathogen in seed tuber soil when levels of the pathogen in field plot soils were below approximately 17 and 5 CFU/g of soil for Russet Burbank and Russet Norkotah, respectively. Field plots planted with seed lots containing high levels of $V$. dahliae in seed tuber soil also resulted in significantly greater levels of $V$. dahliae in postharvest field plot soil compared to field plots planted to seed lots with low levels of the pathogen, as indicated by a significant difference in y-intercept values $(P=0.041)$ (Fig. 7). Significant differences in regression slopes or intercepts were not observed between high and low levels of $V$. dahliae in seed tuber soil with regards to postharvest levels of $V$. dahliae in progeny tuber soil or yield using ANCOVA.

TABLE 1. Verticillium dahliae populations in midseason stem sap, inoculum densities in postharvest progeny tuber soil and postharvest field plot soils, and differences in tuber grades and yields among Russet Burbank and Russet Norkotah seed lots with low (<20 CFU/g) and high (20 CFU/g) concentrations of $V$. dahliae infestation in seed tuber soil prior to planting ${ }^{\mathrm{a}}$

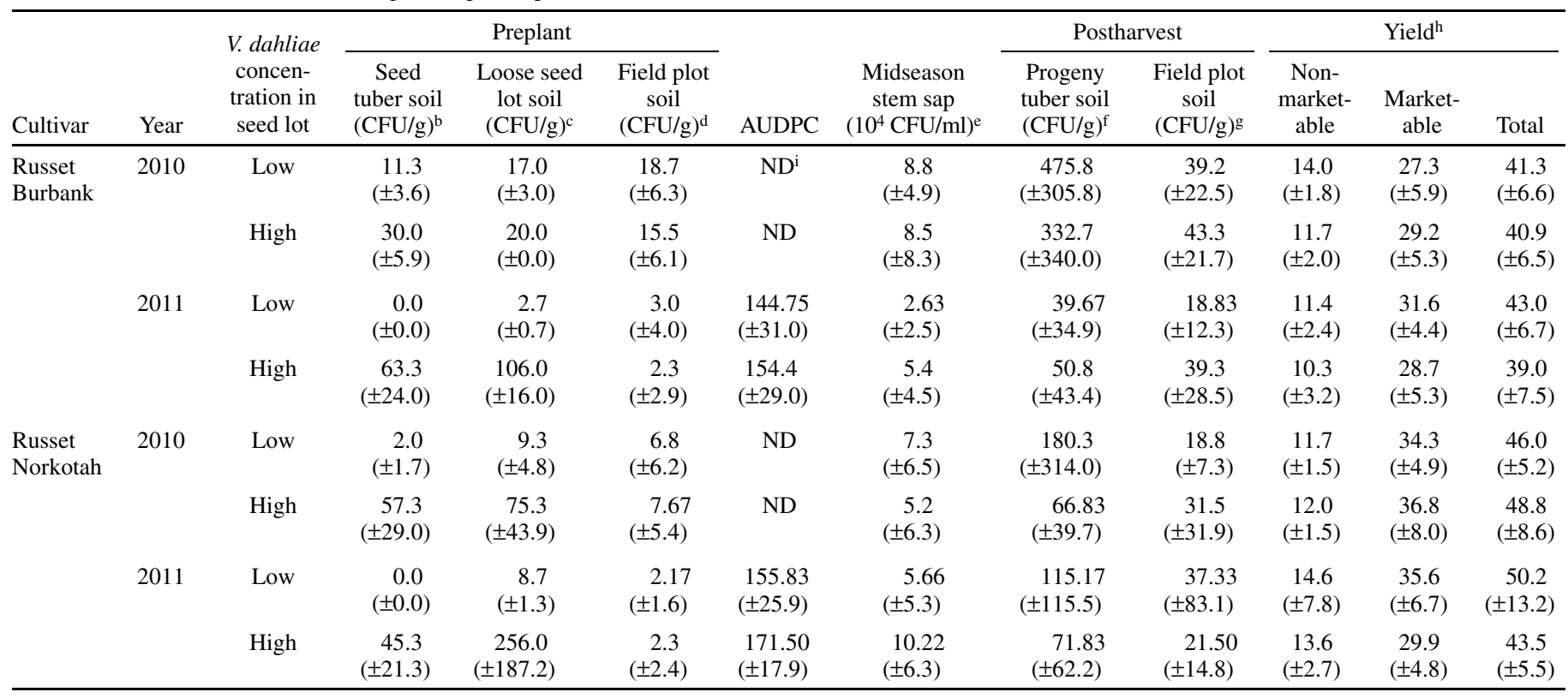

${ }^{a}$ Treatment means are followed by standard deviations in parentheses.

${ }^{\mathrm{b}} V$. dahliae CFUs in soil removed from the surface of seed prior to planting.

${ }^{c}$ V. dahliae CFUs in loose soil collected from bags used to transport seed lots.

${ }^{\mathrm{d}}$ V. dahliae CFUs in field plot soil prior to planting.

e $V$. dahliae CFUs in plant sap from stems removed from plants midseason.

${ }^{\mathrm{f}} V$. dahliae CFUs in soil removed from the surfaces of harvested tubers after grading.

g V. dahliae CFUs in field plot soil at harvest.

${ }^{\mathrm{h}}$ Yield in $\mathrm{kg}$ per $5.95 \mathrm{~m}^{2}$ plot. Tubers in the 113 to $226 \mathrm{~g} \mathrm{(4} \mathrm{to} 8 \mathrm{oz}$ ) and 227 to $340 \mathrm{~g}$ ( 8 to $12 \mathrm{oz}$ ) size classes were considered marketable. Smaller tubers, larger tubers, and tubers classified as culls were considered nonmarketable.

${ }^{i}$ Not determined. 


\section{DISCUSSION}

The use of pathogen-free propagative materials is an important practice to minimize Verticillium wilt, as it reduces the probability of introducing $V$. dahliae into potato production fields. Israel regulates $V$. dahliae in certified seed potatoes (38), but North American seed certification programs do not specifically enumerate or regulate $V$. dahliae levels in certified seed tubers or fields used to produce certified seed lots (47). Two potential sources of $V$. dahliae inoculum are infested soil adhering to seed tubers (seed tuber soil) and infested loose soil associated with seed lot handling and transport (loose seed lot soil). $V$. dahliae was detected in the majority of soil (seed tuber and loose seed lot soil) samples obtained from the 227 seed lots assayed over three years. All isolates belonged to VCG4 and over 93\% of isolates were assigned to VCG4A, which was previously demonstrated to be highly aggressive on potato $(25,37)$. These results demonstrate the significant risk of long-distance movement of $V$. dahliae in seed lots contaminated with infested soil adhering to the surface of seed tubers, as well as in loose soil associated with the handling and transport of seed lots.

While not the emphasis in this study, movement of $C$. coccodes in soil associated with certified potato seed lots also occurs. Primary inoculum of $C$. coccodes consists of soilborne sclerotia

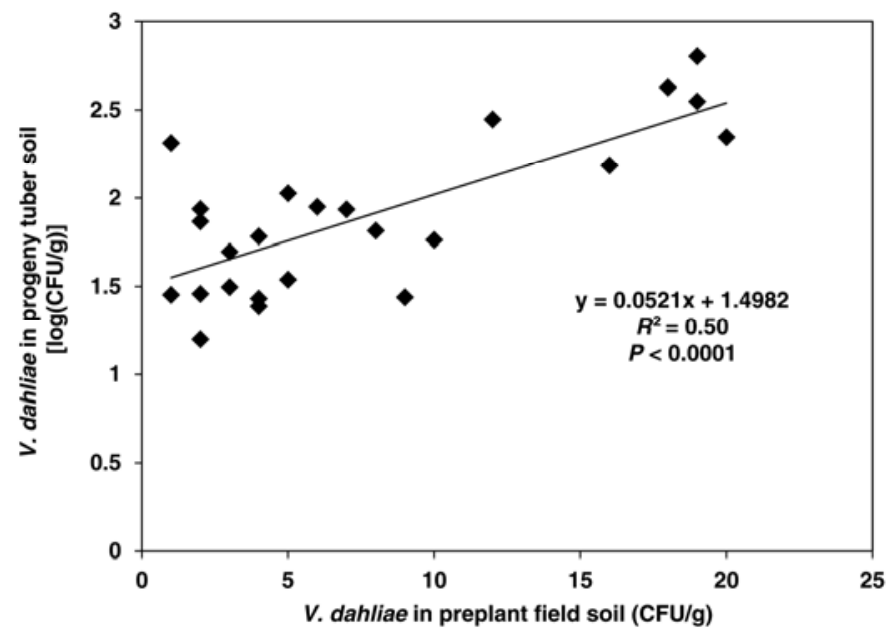

Fig. 4. Relationship between colony forming units of Verticillium dahliae in preplant field plot soil and soil collected from the surface of harvested progeny tubers after grading. Data are combined from two cultivars ('Russet Burbank' and 'Russet Norkotah') planted in field plots in 2010 and 2011.

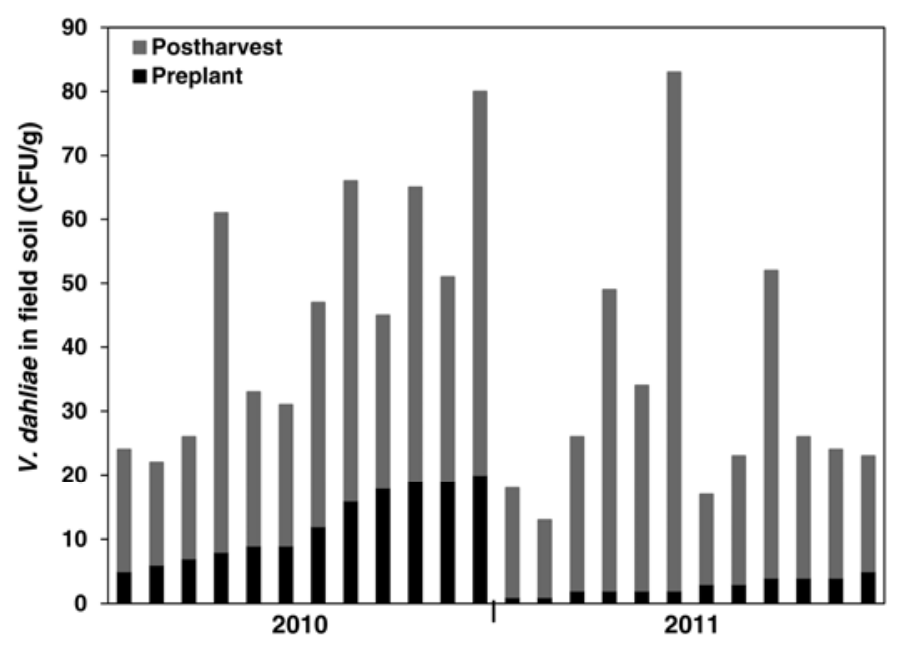

Fig. 5. Colony forming units of Verticillium dahliae in field plot soils sampled at preplant and postharvest. but inoculum may also be present as infected tubers in certified potato seed lots $(11,51)$. Although soilborne inoculum is considered to be the most important source of inoculum for black dot, infected tubers and infested soils in certified seed lots may
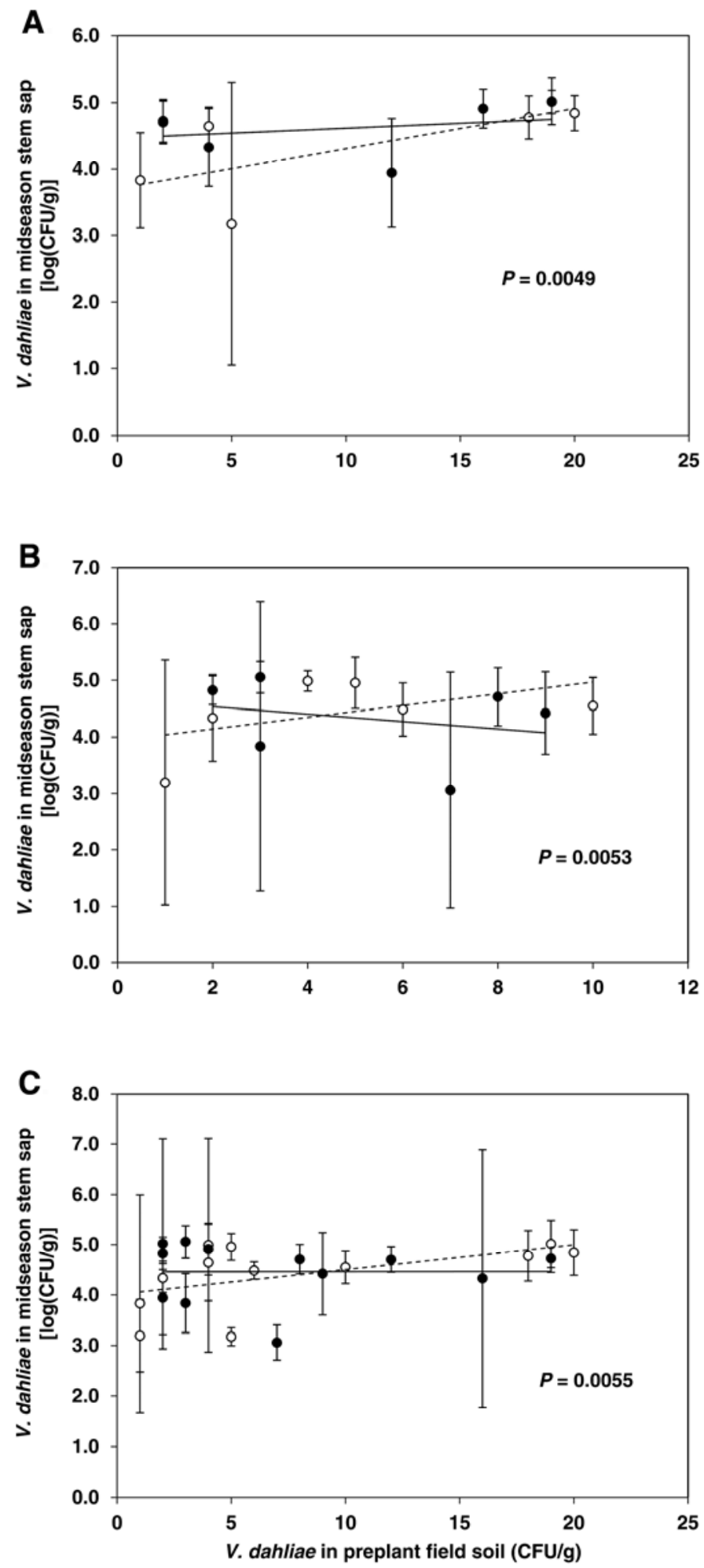

Fig. 6. Relationships between colony forming units of Verticillium dahliae in preplant field plot soil and in stem sap of plants from seed lots of A, 'Russet Burbank', B, 'Russet Norkotah', and C, both cultivars with high (filled circles) and low (open circles) concentrations of $V$. dahliae in seed tuber soil (soil attached to seed tubers). The solid and dotted regression lines represent regressions for high and low concentrations, respectively. $P$ values indicate significant differences between slopes. Error bars represent standard deviations of means. Data are combined from field plots planted in 2010 and 2011. 
contribute to the spread and establishment of the pathogen in commercial production areas. This is important since sclerotia of C. coccodes can persist for many years and the low inoculum threshold (as few as 6 microsclerotia/ $\mathrm{cm}^{3}$ of soil) (35). Further studies are needed to determine the impact of $C$. coccodes-infested seed tuber soil on black dot incidence and severity in the field and under storage conditions.

Planting seed tubers with infested soil can supplement populations of $V$. dahliae already present in commercial fields. All field plot soils exhibited an increase in $V$. dahliae levels following harvest compared to preplant levels. Planting seed lots with high levels of $V$. dahliae in seed tuber soil resulted in increased levels of $V$. dahliae in field plot soils after harvest, indicating that infested seed tuber soil contributes to the annual increase of inoculum observed in potato cropping systems. This is important since the reduction of soilborne inoculum is an effective management practice to reduce Verticillium wilt in the next potato crop. The transport of infested soil associated with seed tuber handling is likely an important method for the distribution and introduction of the aggressive VCG4A potato pathotype into areas not previously cropped to potato. Once established, this pathotype of $V$. dahliae can increase after the cropping of susceptible hosts or cultivars (9). Increased inoculum levels immediately following a potato crop may contribute to more severe symptoms if potatoes are planted in succession or planted without the use of disease management tactics $(7,10,19)$ and may necessitate aggressive and expensive management techniques such as soil fumigation prior to the next potato crop.

The movement of infested soil associated with seed tubers would be of concern anywhere potato production occurs, but may be especially important in large-scale potato production areas such as the Columbia Basin where approximately 2.6 billion seed pieces, equaling 156,300 metric tons, were planted in 2007 $(26,39,46)$. Consequently, the movement of only $10 \mathrm{~g}$ of soil with each metric ton of seed could result in the introduction of approximately $1,563 \mathrm{~kg}$ of potentially infested soil into the region. Even small amounts of infested soil can result in Verticillium wilt problems due to the disease threshold for potato, which can be as low as 10 to $20 \mathrm{CFU} / \mathrm{g}$ of soil (19), and the polyetic nature of the disease. Thus, it may be possible to establish $V$. dahliae in a field through the planting of infected seed (37), or by bringing infested soil associated with seed lots into a field. Preplant soil fumigation is a common practice in the Columbia Basin and other potato production areas to reduce soilborne microsclerotia, the primary source of inoculum for Verticillium wilt of potato. The potential impact of $V$. dahliae in soil on seed may be especially important following soil fumigation since soilborne levels of the pathogen are reduced, thereby increasing the likelihood of Verticillium wilt through the introduction of $V$. dahliae in seed tuber soil.

Increased colonization of potato stems by $V$. dahliae has been correlated with wilt incidence and may contribute to increased microsclerotia production during plant senescence and primary inoculum available for the next season $(8,9)$. V. dahliae was detected in the majority of stem sap samples, indicating that even low concentrations of $V$. dahliae in seed tuber soil can contribute to stem colonization by the pathogen. ANCOVA identified significant interactive effects between concentrations of the pathogen in seed tuber soil and inoculum densities in field plot soil on $V$. dahliae populations in stem sap of both cultivars. Populations of $V$. dahliae in stem sap increased with increasing inoculum densities in field soils when $V$. dahliae concentrations in seed tuber soil were low, but the same relationship was not observed when $V$. dahliae concentrations in seed tuber soil were high. High $V$. dahliae concentrations in seed tuber soil resulted in greater stem sap colonization when $V$. dahliae inoculum densities in field soil were low (approximately $9 \mathrm{CFU} / \mathrm{g}$ for both cultivars combined). This indicates that $V$. dahliae infestation in seed tuber soil can contribute to plant infection and colonization when primary inoculum in field soil is below the disease threshold. However, after a certain threshold of preplant soilborne inoculum in the field is reached the effect of seed tuber soil is less significant. In this study, the regression lines intersected at a lower level of field soil infestation for Russet Norkotah (approximately 4 to $5 \mathrm{CFU} / \mathrm{g}$ of field plot soil), a cultivar which is very susceptible to Verticillium wilt, compared to Russet Burbank (between 15 and 20 CFU/g of field plot soil), a cultivar which is moderately susceptible to Verticillium wilt (53). Infested seed tuber soil can provide inoculum for early season infection of emerging roots during the sprouting of the seed tuber and, as the root system of the potato plant develops, inoculum near the seed piece is probably less important as roots encounter soilborne inoculum. The extent of the interaction is likely dependent on inoculum densities in seed tuber and field soils, the aggressiveness and diversity of $V$. dahliae populations in the field, cultivar, and other factors. In heavily infested fields, contaminated seed tuber soil probably plays a minimal role in Verticillium wilt development but can still augment existing populations of the pathogen.

Yield was not consistently related to levels of $V$. dahliae in preplant seed tuber soil or field plot soil in this study. It is likely that soilborne inoculum in the plots influenced yields, especially in 2010. In 2011, fumigation was more effective in reducing soilborne inoculum in field plots and seed lots with low concentrations of the pathogen in seed tuber soil produced higher marketable and total yields, though the differences were not significant. In addition, cultural factors can affect severity of Verticillium wilt. Low nitrogen, high temperatures, and drought stress can increase Verticillium wilt severity and reduce yield in certain cultivars $(6,17,36)$. In this study, field plots were supplied with sufficient and uniform sources of nitrogen and irrigation throughout the season to simulate best management practices, possibly reducing the impact of the disease on yield.

Levels of $V$. dahliae in field plot soils prior to planting were greater in plots planted to Russet Burbank in 2010 (12 to 20 $\mathrm{CFU} / \mathrm{g}$ of soil) compared with other plots (1 to $9 \mathrm{CFU} / \mathrm{g}$ of soil) and a relationship between increasing levels of soilborne inoculum and greater levels of the pathogen in stem sap was observed. These results are consistent with previous research concluding that soilborne inoculum present in the field is a major source of inoculum for the current season $(8,12)$. Greater preplant

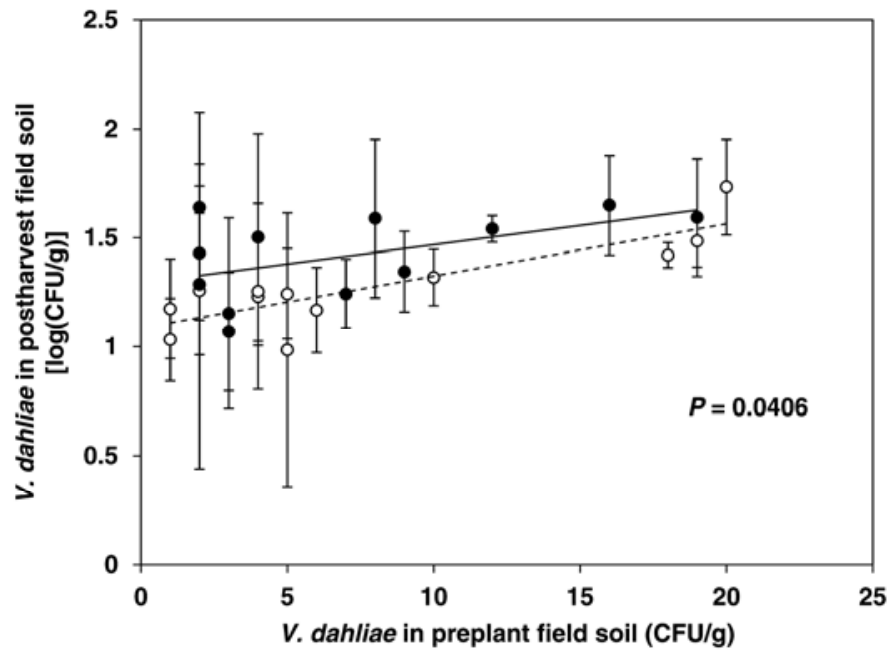

Fig. 7. Relationship between colony forming units of Verticillium dahliae in preplant field plot soil and in postharvest field plot soil after planting seed lots of 'Russet Burbank' and 'Russet Norkotah' with high (filled circles) and low (open circles) concentrations of $V$. dahliae in seed tuber soil (soil attached to seed tubers). The solid and dotted regression lines represent regressions for high and low concentrations, respectively. $P$ value indicates a significant difference between $y$ intercepts. Error bars represent standard deviations of means. Data are combined from field plots planted in 2010 and 2011. 
levels of $V$. dahliae in field plot soils were also significantly related to increased levels of $V$. dahliae in progeny tuber soil collected from the surface of harvested tubers after grading. These results demonstrate that $V$. dahliae can be moved from field to field via infested soil associated with harvested tubers, emphasizing the importance of thorough cleaning of all equipment after harvest and grading. It is also not advisable to return soil from harvesting operations back to production fields, as it may be highly infested with $V$. dahliae. It may also be possible for these infested soils to be disseminated by wind or water (13). Potentially infested soils that are removed from the field during harvest should be removed from the vicinity or be disinfested using soil solarization or fumigation to reduce or eliminate $V$. dahliae inoculum that is present.

The results of this study show that $V$. dahliae can be transported via infested soil associated with certified seed tubers. It is possible for $V$. dahliae to be moved from seed-producing states to commercial production areas across the United States. Once introduced into commercial production areas the potential exists for infested soil to be moved from field to field during the transport, distribution, and planting of seed tubers. In addition, field-to-field movement can occur via shared equipment, irrigation water, or even wind dispersal. Some seed lots contained the pathogen at extremely high concentrations (over $500 \mathrm{CFU} / \mathrm{g}$ ) which is likely to contribute to an annual increase of $V$. dahliae inoculum in potato fields. It should be noted that the detection limit of the dry-plating assay only allowed for the reliable quantification of up to $500 \mathrm{CFU} / \mathrm{g}$ of soil and some seed lots exhibited greater concentrations of the pathogen in associated soils. Regardless of $V$. dahliae concentrations, infested seed tuber soil can introduce the pathogen or augment inoculum densities already present in the fields. The information reported here suggests that controlling $V$. dahliae inoculum associated with seed tubers may be justified within the United States, as is done in Israel.

Reduced wilt and increased yields following seed treatments aimed at reducing Verticillium wilt have previously been reported, and the effects of these treatments were attributed to the reduction of $V$. dahliae in infested soil on the surface of seed tubers $(41,43)$. All, or nearly all, fields in the Columbia Basin production area receive preplant management practices such as soil fumigation or rotations with green manures or nonhost crops. The long-term benefit of reducing $V$. dahliae propagules through preplant seed treatments or planting Verticillium-free potato seed tubers may outweigh the short-term costs of chemical treatments by reducing the introduction of additional inoculum, reducing the need or prolonging the effectiveness of costly soil fumigation, and improving sustainability.

\section{ACKNOWLEDGMENTS}

We thank the Oregon and Washington State Potato Commissions for financial support of this project and J. Holcomb and T. Cummings for technical assistance. Thank you to grower-cooperators. PPNS No. 0595, Department of Plant Pathology, College of Agricultural, Human, and Natural Resource Sciences Agricultural Research Center, Project No. WNP00678, Washington State University, Pullman, WA 99164-6430.

\section{LITERATURE CITED}

1. Ayers, G. W. 1952. Studies on Verticillium wilt of potatoes. Am. Potato J. 29:201-205.

2. Bao, J. R., Katan, J., Shabi, E., and Katan, T. 1998. Vegetative-compatibility groups in Verticillium dahliae from Israel. Eur. J. Plant Pathol. 104:263-269.

3. Berbegal, M., Ortega, A., Jiménez-Gasco, M. M., Olivares-García, C., Jiménez-Díaz, R. M., and Armengol, J. 2010. Genetic diversity and host range of Verticillium dahliae isolates from artichoke and other vegetable crops in Spain. Plant Dis. 94:396-404.

4. Butterfield, E. J., and Devay, J. E. 1977. Reassessment of soil assays for Verticillium dahliae. Phytopathology 67:1073-1078.
5. Cook, R., Ford, E., and Snyder, W. 1968. Mating types, sex, dissemination, and possible sources of clones, of Hypomyces (Fusarium) solani $\mathrm{f}$. pisi in South Australia. Aust. J. Agric. Res. 19:253-259.

6. Davis, J. R., and Everson, D. O. 1986. Relation of Verticillium dahliae in soil and potato tissue, irrigation method, and $\mathrm{N}$-fertility to Verticillium wilt of potato. Phytopathology 76:730-736.

7. Davis, J. R., Huisman, O. C., Westermann, D. T., Hafez, S. L., Everson, D. O., Sorensen, L. H., and Schneider, A. T. 1996. Effects of green manures on Verticillium wilt of potato. Phytopathology 86:444-453.

8. Davis, J. R., Pavek, J. J., and Corsini, D. L. 1983. A sensitive method for quantifying Verticillium dahliae colonization in plant tissue and evaluating resistance among potato genotypes. Phytopathology 73:1009-1014.

9. Davis, J. R., Pavek, J. J., Corsini, D. L., Sorensen, L. H., Schneider, A. T., Everson, D. O., Westerman, D. T., and Huisman, O. C. 1994. Influence of continuous cropping of several potato clones on the epidemiology of Verticillium wilt of potato. Phytopathology 84:207-214.

10. Davis, J. R., Sorensen, L. H., Stark, J. C., and Westermann, D. T. 1990. Fertility and management practices to control Verticillium wilt of the Russet Burbank potato. Am. Potato J. 67:55-65.

11. Dung, J. K. S., Ingram, J., Cummings, T. F., and Johnson, D. A. 2012. Impact of seed lot infection on the development of black dot and Verticillium wilt of potato in Washington. Plant Dis. 96:1179-1184.

12. Dung, J. K. S., and Johnson, D. A. 2012. Roles of infected seed tubers and soilborne inoculum on Verticillium wilt of 'Russet Burbank' potato. Plant Dis. 96:379-383.

13. Easton, G. D., Nagle, M. E., and Bailey, D. L. 1969. A method of estimating Verticillium albo-atrum propagules in field soil and irrigation waste water. Phytopathology 59:1171-1172.

14. Easton, G. D., Nagle, M. E., and Bailey, D. L. 1972. Verticillium alboatrum carried by certified seed potatoes into Washington and control by chemicals. Am. Potato J. 49:397-402.

15. Ebihara, Y., Nagao, H., Koike, M., Shiraishi, T., and Iijima, T. 1999. How do Japanese isolates of Verticillium dahliae correspond with standardized VCG testers? Mycoscience 40:333-343.

16. Fisher, R. A. 1960. The Design of Experiments. 7th ed. Hafner, New York.

17. Francl, L. J., Madden, L. V., Rowe, R. C., and Riedel, R. M. 1990. Correlation of growing season environmental variables and the effect of early dying on potato yield. Phytopathology 80:425-432.

18. Green, R. J. 1969. Survival and inoculum potential of conidia and microsclerotia of Verticillium albo-atrum in soil. Phytopathology 59:874876.

19. Hamm, P. B., Ingham, R. E., Jaeger, J. R., Swanson, W. H., and Volker, K. C. 2003. Soil fumigant effects on three genera of potential soilborne pathogenic fungi and their effect on potato yield in the Columbia Basin of Oregon. Plant Dis. 87:1449-1456.

20. Harveson, R. M., Hanson, L. E., and Hein, G. L., eds. 2009. Compendium of Beet Diseases and Pests. American Phytopathological Society, St. Paul, $\mathrm{MN}$.

21. Heijbroek, W. 1988. Dissemination of rhizomania by soil, beet seeds and stable manure. Eur. J. Plant Pathol. 94:9-15.

22. Hoyman, W. G. 1974. Consequence of planting Norgold Russet seed infected with Verticillium albo-atrum. Am. Potato J. 51:22-25.

23. Hoyos, G., Zambino, P., and Anderson, N. 1991. An assay to quantify vascular colonization of potato by Verticillium dahliae. Am. J. Potato Res. 68:727-742.

24. Joaquim, T. R., and Rowe, R. C. 1990. Reassessment of vegetative compatibility relationships among strains of Verticillium dahliae using nitrate-nonutilizing mutants. Phytopathology 80:1160-1166.

25. Joaquim, T. R., and Rowe, R. C. 1991. Vegetative compatibility and virulence of strains of Verticillium dahliae from soil and potato plants. Phytopathology 81:552-558.

26. Johnson, D. A. 2009. Transmission of Phytophthora infestans from infected potato seed tubers to emerged shoots. Plant Dis. 94:18-23.

27. Johnson, D. A., and Dung, J. K. S. 2010. Verticillium wilt of potato-the pathogen, disease and management. Can. J. Plant Pathol. 32:58-67.

28. Korolev, N., Katan, J., and Katan, T. 2000. Vegetative compatibility groups of Verticillium dahliae in Israel: Their distribution and association with pathogenicity. Phytopathology 90:529-536.

29. Kuehl, R. O. 1999. Design of Experiments: Statistical Principles of Research Design and Analysis. 2nd ed. Duxbury Press, Pacific Grove, CA.

30. Kutner, M. H., Nachtsheim, C. J., Neter, J., and Li, W. 2005. Applied Linear Statistical Models. 5th ed. McGraw-Hill/Irwin, New York.

31. Mallows, C. L. 1973. Some comments on Cp. Technometrics 15:661-675.

32. Martinson, C. A., and Horner, C. E. 1962. Importance of nonhosts in maintaining the inoculum potential of Verticillium. Phytopathology 52:742.

33. Menzies, J. D., and Griebel, G. E. 1967. Survival and saprophytic growth of Verticillium dahliae in uncropped soil. Phytopathology 57:703-709.

34. Mol, L. 1995. Effect of plant roots on the germination of microsclerotia of Verticillium dahliae. II. Quantitative analysis of the luring effect of crops. Eur. J. Plant Pathol. 101:679-685. 
35. Nitzan, N., Cummings, T. F., and Johnson, D. A. 2008. Disease potential of soil- and tuberborne inocula of Colletotrichum coccodes and black dot severity on potato. Plant Dis. 92:1497-1502.

36. Nnodu, E., and Harrison, M. 1979. The relationship between Verticillium albo-atrum inoculum density and potato yield. Am. Potato J. 56:11-25.

37. Omer, M. A., Johnson, D. A., and Rowe, R. C. 2000. Recovery of Verticillium dahliae from North American certified seed potatoes and characterization of strains by vegetative compatibility and aggressiveness. Am. J. Potato Res. 77:325-331.

38. Oppenheimer, J. 1981. Seedpotato certification in Israel. Am. J. Potato Res. 58:489-493.

39. Pavek, M., and Thornton, R. 2005. A survey of stand establishment and in-row spacing uniformity in Washington potato fields. Am. J. Potato Res. 82:463-469.

40. Powelson, M. L., and Rowe, R. C. 1993. Biology and management of early dying of potatoes. Annu. Rev. Phytopathol. 31:111-126.

41. Robinson, D. B., and Ayers, G. W. 1953. The control of Verticillium wilt of potatoes by seed treatment. Can. J. Agric. Sci. 33:147-152.

42. Robinson, D. B., and Ayers, G. W. 1961. Verticillium wilt of potato in relation to vascular infection of the tuber. Can. J. Plant Sci. 41:703-708.

43. Robinson, D. B., Larson, R. H., and Walker, J. C. 1957. Verticillium wilt of potato in relation to symptoms, epidemiology and variability of the pathogen. University of Wisconsin Agricultural Experiment Station Bulletin 202.

44. Rowe, R. C., Davis, J. R., Powelson, M. L., and Rouse, D. I. 1987. Potato early dying: Causal agents and management strategies. Plant Dis. 71:482-489.
45. Schnathorst, W. C. 1981. Life cycle and epidemiology of Verticillium. Pages 81-111 in: Fungal Wilt Diseases of Plants. M. E. Mace, A. A. Bell, and C. H. Beckman, eds. Academic Press, New York.

46. Secor, G. A., and Johnson, S. B. 2008. Seed tuber health before and during planting. Pages 43-53 in: Potato Health Management. 2nd ed. D. A. Johnson, ed. American Phytopathological Society, St. Paul, MN.

47. Shepard, J. F., and Claftin, L. E. 1975. Critical analyses of the principles of seed potato certification. Annu. Rev. Phytopathol. 13:271-293.

48. Strausbaugh, C. A. 1993. Assessment of vegetative compatibility and virulence of Verticillium dahliae isolates from Idaho potatoes and tester strains. Phytopathology 83:1253-1258.

49. Strausbaugh, C. A., Schroth, M. N., Weinhold, A. R., and Hancock, J. G. 1992. Assessment of vegetative compatibility of Verticillium dahliae tester strains and isolates from California potatoes. Phytopathology 82:61-68.

50. Subbarao, K. V., Hubbard, J. C., and Koike, S. T. 1999. Evaluation of broccoli residue incorporation into field soil for Verticillium wilt control in cauliflower. Plant Dis. 83:124-129.

51. Tsror (Lahkim), L., Aharon, M., and Erlich, O. 1999. Survey of bacterial and fungal seedborne diseases in imported and domestic potato seed tubers. Phytoparasitica 27:215-226.

52. Tsror, L., Hazanovsky, M., Mordechi-Lebiush, S., and Sivan, S. 2001. Aggressiveness of Verticillium dahliae isolates from different vegetative compatibility groups to potato and tomato. Plant Pathol. 50:477-482.

53. Whitworth, J. L., and Davidson, R. D. 2008. Quality seed: Seed improvement, cultivar and seed lot selection, and certification. Pages 31-41 in: Potato Health Management. 2nd ed. D. A. Johnson, ed. American Phytopathological Society, St. Paul, MN. 